\title{
Fiber Quality Traits under Different Environments/Sowing Conditions in Upland Cotton (Gossypium hirsutum L.)
}

\author{
Pinki", S.S. Siwach, R.S. Sangwan, Sombir Singh, V.S. Mor, Shiwani Mandhania, \\ Sunayana and Neha Rohila
}

CCS Haryana Agricultural University, Hisar, Haryana, India

*Corresponding author

\section{A B S T R A C T}

\begin{tabular}{|l|}
\hline K e y w o r d s \\
$\begin{array}{l}\text { Cotton, Boll retention, } \\
\text { Sowing period, Different } \\
\text { environments }\end{array}$ \\
\hline Article Info \\
\hline $\begin{array}{l}\text { Accepted: } \\
12 \text { April } 2018 \\
\text { Available Online: } \\
10 \text { May } 2018\end{array}$ \\
\hline
\end{tabular}

Keywords

Cotton, Boll retention, environments

\section{Introduction}

Cotton (Gossypium hirsutum L.) is an important commercial crop grown all over the world which is mainly grown for its fiber. Upland cotton dominates the world's cotton fiber production accounting for approximately $90 \%$ of the total production. Fiber from various species within this genus had been used for several thousand years for clothing and other textiles in India (Khan, 2011, Batool and Khan, 2012). Cotton is regarded as multipurpose agricultural product and used in the manufacturing of more than 1000 major products. Not only its fiber is important, but also the cottonseed is of economic importance and is used as an oilseed.
Cotton is highly responsive to changes in temperature, humidity, and soil moisture, which may affect its yield, yield components and fiber properties. Climatic, soil, insect, disease and cultural conditions differ from one place to another, and also differ from year to year at the same location. Therefore, genetic and environmental variability for cotton yield, yield components and lint quality traits should be estimated at different environments to conduct successful breeding program (Killi et al., 2005).

Cotton fiber quality is based primarily on parameters of length, strength and micronaire. Advances in textile manufacturing have increased demands on the physical properties 
of cotton. Fiber quality is held to high international standards but the lacks of sufficient financial premiums for producing such quality have not stimulated better fiber quality cultivars.

This accentuates the long standing challenge for cotton breeders to produce premium fiber quality while simultaneously maintaining yield (Clement et al., 2014).

With the modernization of spinning industry and quality conscious consumers, there is an increased emphasis on the production of superior quality cotton (Srinivas et al., 2015). Development of cotton varieties and hybrids having greater yield potential with acceptable fiber characteristics is the main objective of cotton breeders.

Through developing the cotton varieties having both high fiber and oil yield, it would be possible to reduce edible oil imports in the country (Munawar et al., 2013).

\section{Materials and Methods}

The experiment was conducted during kharif 2015 \& 2016 having three cultivars H 1098-I, $\mathrm{H} 1300$ and $\mathrm{H} 1316$ of upland cotton grown at CCS Haryana Agricultural University, Hisar in randomized block design replicated six times each in eight rows of $6 \mathrm{~m}$ length with a spacing of $67.5 \times 30 \mathrm{~cm}$. These varieties were grown in six environments that comprises of three sowings periods (Early: first fortnight of April, normal: first fortnight of May and late: end of May/early June) during the year 2015 \& 2016 (Table 1).

For fiber quality parameters the lint of five plants used for recording morphological data will be bulked and same will be used for fiber quality analysis from CIRCOT Lab, Sirsa. Fiber quality will be recorded for the following traits:

\section{Upper half mean length $(2.5$ per cent span length) (mm)}

2.5 per cent span length $(\mathrm{mm})$ is defined as the distance spanned by a specified percentage of fibers in the specimen being tested. Fiber length at 2.5 per cent span was estimated and expressed in millimeters.

\section{Uniformity ratio (\%)}

The Uniformity ratio is the ratio of $50 \%$ Upper half mean length to $2.5 \%$ Upper half mean length expressed as percentage. Uniformity ratio was found out by using HVI instrument and computed as below.

$$
\text { Uniformity ratio }=\frac{50 \% \text { Span length }}{2.5 \% \text { Span length }} \times 100
$$

\section{Fiber strength $\left(\mathrm{g} \mathrm{tex}^{-1}\right)$}

Fiber strength is expressed as tenacity denoting the maximum tension the fiber is able to sustain before the break. The fiber strength was determined by using HVI instrument, expressed in grams per tex and is computed as below:

Fiber strength $\left(\mathrm{g}\right.$ tex $\left.^{-1}\right)=[$ Breaking strength $(\mathrm{kg}) /$ Weight of tuff $(\mathrm{mg})] \times$ Length of sample $(\mathrm{mm})$

\section{Fiber fineness $\left(\mu \mathrm{g} \mathrm{inch}^{-1}\right)$}

Fiber fineness is more commonly expressed as linear density or weight per unit length and popularly known as micronaire. This character was measured by micronaire module of the HVI instrument.

When the chamber lid is closed, a piston at the chamber bottom compresses the fiber to a fixed and known volume. A regulated stream of air is then forced through the sample and 
the pressure drop across the sample is measured as the fineness value and expressed in $\mu \mathrm{g}$ inch $^{-1}$.

\section{Results and Discussion}

Upland cotton (Gossypium hirsutum L.) is the most important fiber crop in the world. Fiber quality of a particular cotton genotype is a combination of different characters including staple length, fiber strength, fineness, and uniformity with extreme importance (Poehlman and Sleper, 1995; Ali et al., 2008). In fact, fiber traits that establish fiber quality set the basis for marketing and sale of cotton throughout the world (Asif et al., 2008). Furthermore, these characteristics were associated with the proficient spinning and weaving processes that alter the fiber into fabrics. Keeping this in view, it is need of the day to identify the sowing period which resulted in better fiber quality parameters.

Fiber quality characters were least affected by environmental factors. Minor differences were observed in $E_{1}$ and $E_{4}$ as having higher values of fiber quality traits.

In the variety $\mathrm{H}$ 1098- I upper half mean length (UHML) $\mathrm{mm}$ in $\mathrm{E}_{1}$ was 27.9, uniformity index was $82.3(\%)$, strength (g/tex) was 29.6 and micronaire value (ug/inch) was 4.6. In $\mathrm{E}_{2}$ UHML was $25.7 \mathrm{~mm}$, UI was $81.3 \%$, strength was $26.4 \mathrm{~g} /$ tex and mic. value was $4.7 \mathrm{ug} / \mathrm{inch}$. In E3 UHML was $25.6 \mathrm{~mm}$, UI was $81.3 \%$, strength was $26.5 \mathrm{~g} /$ tex and mic. value was $4.6 \mathrm{ug} / \mathrm{inch}$. In $\mathrm{E}_{4}$ UHML was $27.9 \mathrm{~mm}$, UI was $82.3 \%$, strength was 28.9 $\mathrm{g} /$ tex and mic. value was $4.5 \mathrm{ug} / \mathrm{inch}$. In $\mathrm{E}_{5}$ UHML was $26.0 \mathrm{~mm}$, UI was $81.5 \%$, strength was $25.8 \mathrm{~g} /$ tex and mic. value was $4.6 \mathrm{ug} / \mathrm{inch}$. In $\mathrm{E}_{6}$ UHML was $25.4 \mathrm{~mm}$, UI was $81.4 \%$, strength was $25.5 \mathrm{~g} /$ tex and mic. value was 4.6 ug/inch.

In the variety $\mathrm{H} 1300$ upper half mean length (UHML) $\mathrm{mm}$ in $\mathrm{E}_{1}$ was 26.7 , uniformity index was $82.0(\%)$, strength (g/tex) was 27.9 and micronaire value (ug/inch) was 4.9. In $\mathrm{E}_{2}$ UHML was $25.8 \mathrm{~mm}$, UI was $81.3 \%$, strength was $27.5 \mathrm{~g} /$ tex and mic. value was $4.5 \mathrm{ug} / \mathrm{inch}$. In $\mathrm{E}_{3}$ UHML was $25.4 \mathrm{~mm}$, UI was $81.0 \%$, strength was $27.0 \mathrm{~g} /$ tex and mic. value was 4.7 ug/inch. In $\mathrm{E}_{4}$ UHML was $25.3 \mathrm{~mm}$, UI was $81.3 \%$, strength was $27.6 \mathrm{~g} /$ tex and mic. value was $4.8 \mathrm{ug} / \mathrm{inch}$. In $\mathrm{E}_{5}$ UHML was $25.7 \mathrm{~mm}$, UI was $81.2 \%$, strength was $26.9 \mathrm{~g} /$ tex and mic. value was $4.6 \mathrm{ug} / \mathrm{inch}$. In $\mathrm{E}_{6} \mathrm{UHML}$ was $25.2 \mathrm{~mm}$, UI was $81.1 \%$, strength was $25.5 \mathrm{~g} / \mathrm{tex}$ and mic. value was $4.6 \mathrm{ug} / \mathrm{inch}$.

Table.1 Sowing dates and different environments in 2015 \& 2016

\begin{tabular}{|c|c|c|c|}
\hline \multicolumn{2}{|c|}{ Environment } & Date of Sowing & $\begin{array}{c}\text { Environment } \\
\text { Designation }\end{array}$ \\
\hline Year & Sowing period & & $\mathrm{E}_{1}$ \\
\hline $\mathbf{2 0 1 5}$ & Early & 10 April & $\mathrm{E}_{2}$ \\
\hline & Normal & 15 May & $\mathrm{E}_{3}$ \\
\hline $\mathbf{2 0 1 6}$ & Late & 5 June & $\mathrm{E}_{4}$ \\
\hline & Early & 26 April & $\mathrm{E}_{5}$ \\
\hline
\end{tabular}


Table.2 Mean values of fiber quality traits in different environments in H- 1098- I

\begin{tabular}{|c|c|c|c|c|c|c|}
\hline & $\mathbf{E}_{1}$ & $\mathbf{E}_{2}$ & $\mathbf{E}_{3}$ & $\mathbf{E}_{4}$ & $\mathbf{E}_{5}$ & $\mathbf{E}_{6}$ \\
\hline UHML(mm) & 27.9 & 25.7 & 25.6 & 27.9 & 26.0 & 25.4 \\
\hline UI & 82.3 & 81.3 & 81.3 & 82.3 & 81.5 & 81.4 \\
\hline Strength (g/tex) & 29.6 & 26.4 & 26.5 & 28.9 & 25.8 & 25.5 \\
\hline Mic. & 4.6 & 4.7 & 4.6 & 4.5 & 4.6 & 4.6 \\
\hline \multicolumn{7}{|c|}{ Table.3 Mean values of fiber quality traits in different environments in H 1300} \\
\hline & $\mathbf{E}_{1}$ & $\mathbf{E}_{2}$ & $\mathbf{E}_{3}$ & $\mathbf{E}_{4}$ & $\mathbf{E}_{5}$ & $\mathbf{E}_{6}$ \\
\hline UHML(mm) & 26.7 & 25.8 & 25.4 & 25.28 & 25.7 & 25.2 \\
\hline UI & 82.0 & 81.3 & 81.0 & 81.3 & 81.2 & 81.1 \\
\hline Strength (g/tex) & 27.9 & 27.5 & 27.0 & 27.6 & 26.9 & 25.5 \\
\hline Mic. & 4.9 & 4.5 & 4.7 & 4.8 & 4.6 & 4.6 \\
\hline \multicolumn{7}{|c|}{ Table.4 Mean values of fiber quality traits in different environments in H 1316} \\
\hline & $\mathrm{E}_{1}$ & $\mathrm{E}_{2}$ & $\mathrm{E}_{3}$ & $\mathrm{E}_{4}$ & $\mathrm{E}_{5}$ & $\mathrm{E}_{6}$ \\
\hline UHML(mm) & 27.3 & 25.8 & 25.7 & 26.9 & 25.2 & 25.4 \\
\hline UI & 82.3 & 81.7 & 81.3 & 82.0 & 81.5 & 81.3 \\
\hline Strength (g/tex) & 29.2 & 27.4 & 26.3 & 29.0 & 26.8 & 25.5 \\
\hline Mic. & 4.8 & 4.9 & 4.9 & 4.7 & 4.9 & 4.8 \\
\hline
\end{tabular}

In the variety $\mathrm{H} 1316$ upper half mean length (UHML) $\mathrm{mm}$ in $\mathrm{E}_{1}$ was 27.3 , uniformity index was $82.3(\%)$, strength (g/tex) was 29.2 and micronaire value (ug/inch) was 4.8. In $\mathrm{E}_{2}$ UHML was $25.8 \mathrm{~mm}$, UI was $81.7 \%$, strength was $27.4 \mathrm{~g} / \mathrm{tex}$ and mic. value was 4.9 ug/inch. In $\mathrm{E}_{3}$ UHML was $25.7 \mathrm{~mm}$, UI was $81.3 \%$, strength was $26.3 \mathrm{~g} / \mathrm{tex}$ and mic. value was $4.9 \mathrm{ug} / \mathrm{inch}$. In $\mathrm{E}_{4}$ UHML was $26.9 \mathrm{~mm}$, UI was $82.0 \%$, strength was $29.0 \mathrm{~g} / \mathrm{tex}$ and mic. value was $4.7 \mathrm{ug} / \mathrm{inch}$. In $\mathrm{E}_{5} \mathrm{UHML}$ was $25.2 \mathrm{~mm}$, UI was $81.5 \%$, strength was 26.8 $\mathrm{g} / \mathrm{tex}$ and mic. value was $4.9 \mathrm{ug} / \mathrm{inch}$. In $\mathrm{E}_{6}$ UHML was $25.4 \mathrm{~mm}$, UI was $81.3 \%$, strength was $25.5 \mathrm{~g} / \mathrm{tex}$ and mic. value was $4.8 \mathrm{ug} / \mathrm{inch}$.

UHML, UI, strength and micronaire value were high in $E_{1}$ and $E_{4}$ in all the three varieties. So it was observed that early sown condition was better than normal and late sown conditions.
UHML or fiber length ranges from 25.2- 27.9 in all the six environments in all the three varieties. Uniformity index ranges from 8182.3 in all the three varieties. Fiber trength ranges from 25.2- 29.6 in all the three varieties. Micronaire value ranges from 4.5 4.9 .

Similar results were reported by Kilii et al., 2005 for mean values of all the fiber traits. Fiber quality traits were better in early sown conditions because under early sown condition fiber gets more time for their development and maturity. So the fiber quality traits i.e. length, strength, uniformity were better as compared to normal and late sown conditions. Late sown condition exhibited poorer boll and fiber properties, indicating negative effects of reduced heat unit accumulation by later bolls (Michel and Randy, 1997). 


\section{References}

Ali, M. A., Khan, A. I., Awan, S. I., Ali, S. and Niaz, S. (2008). Genetics of fiber quality traits in Cotton (Gossypium hirsutum L.). Austr. J. Crop Sci. 2(1): 10-17.

Asif, M., Mirza, J. I. and Zafar, Y. (2008). Genetic analysis for fiber quality traits of some cotton genotypes. Pak. J. Bot. 40(3): 1209-1215.

Batool, S. and Khan, N.U. (2012). Diallel studies and heritability estimates using Hayman's approach in upland cotton. SABRAO J. Breed. Genet. 44(2): 322338.

Clement, J.D., Constable, G.A.and S.M. Liu. (2014). Increasing cotton seed Fiber density as a breeding strategy to improve Fiber fineness. Field Crops Res. 160: 81-89.

Khan, N.U. (2011). Economic heterosis for morpho-yield traits in F1 and F2 diallel crosses of upland cotton. SABRAO J. Breed. Genet. 43(2): 144- 164.
Killi, F. and Gencer, O. (2005). Estimates of genotype - environment interactions and heritabilities of lint yield and technological properties in cotton (Gossypium hirsutum L.). Proce. 1st National Field Crops Congress, 25-29 April 1994: 260-63.

Michael A. J. and Randy, W. (1997). Fiber Yield and Quality of Cotton Grown at Two Divergent Population Densities. Crop Sci. 38: 1190 - 1195.

Munawar, M. and Malik, T.A. (2013). Correlation and genetic architecture of seed traits and oil content in Gossypium hirsutum L. J. Plant Breed. Genet. 1(02): 56-61.

Poehlman, J. M. and Sleper, D. A. (1995). Breeding field crops. Lowa State Univ. Press

Srinivas, B., Bhadru, D. and Brahmeswara, M.V. (2015). Correlation and path coefficient analysis for seed cotton yield and its components in American cotton (Gossypium hirsutum L.). Agric. Sci. Digest. 35 (1): 13-18

\section{How to cite this article:}

Pinki, S.S. Siwach, R.S. Sangwan, Sombir Singh, V.S. Mor, Shiwani Mandhania, Sunayana and Neha Rohila. 2018. Fiber Quality Traits under Different Environments/Sowing Conditions in Upland Cotton (Gossypium hirsutum L.). Int.J.Curr.Microbiol.App.Sci. 7(05): 1291-1295. doi: https://doi.org/10.20546/ijcmas.2018.705.156 